
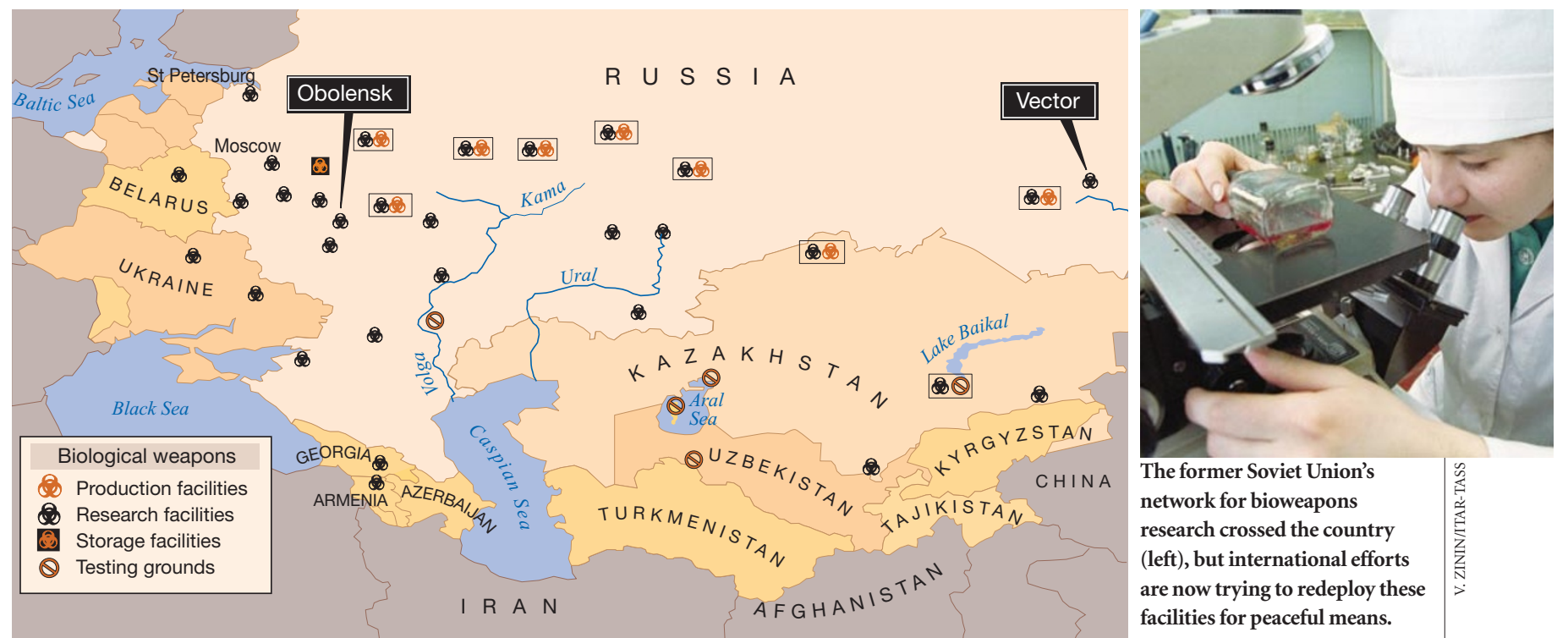

\title{
Still out in the cold
}

\section{Collaborations between Western researchers and former Soviet bioweapons scientists could benefit both parties. But mistrust and bureaucracy are getting in the way, says Geoff Brumfiel.}

$\mathrm{n}$
$\mathrm{re}$
$\mathrm{la}$ n autumn 2001, three American researchers sped down a deserted twolane road that cuts through the forests south of Moscow. They were travelling to Obolensk, once a secret city and home to one of the former Soviet Union's largest bioweapons research complexes - the State Research Center for Applied Microbiology.

The researchers were part of a programme, funded by the Pentagon, that aims to keep Russia's former bioweapons scientists gainfully employed on useful projects. Despite the dilapidated surroundings in Obolensk, the visitors were enthused by the opportunities for collaboration. The crumbling concrete buildings "looked almost like a ghetto", recalls Rebecca Morton, a veterinary scientist at Oklahoma State University in Stillwater. But after two weeks, she had hatched a plan to work with Obolensk researcher Vitaly Pavlov on endemic Eurasian strains of Francisella tularensis. This bacterium causes tularaemia, a potentially fatal and extremely infectious disease that affects the liver, spleen, lungs and lymph nodes, which was studied at Obolensk because of its bioweapons potential.

Morton's project, which would study the surface proteins on different strains of the bacterium in an effort to develop strainspecific diagnostic tests, is exactly the sort of initiative that the programme is designed to support. But almost 18 months down the line, she is no nearer to getting the project under way. Although her proposal has had positive peer review, the funding request is still winding its way through the Pentagon's bureaucracy. "I haven't spoken to Vitaly for a while, because I don't have much to tell him," says Morton. "It's a little embarrassing."

\section{Obstacle course}

Other researchers who hope to set up collaborations at the Obolensk centre and its sister facility, the State Research Center of Virology and Biotechnology, known as Vector, at Koltsovo near Novosibirsk in Siberia, are experiencing similar delays. Cultural differences, mistrust between Russia and the United States, and bureaucratic obstacles on both sides are all conspiring to stall promising avenues of research.

After the demise of the Soviet Union in 1991, US funds flowed rapidly to former nuclear scientists and rocket engineers, with the goal of preventing them from accepting lucrative offers from countries eager to acquire an arsenal of ballistic nuclear weapons. But bioweaponeers were left out in the cold. The reason, according to Amy Smithson, a senior associate at the Henry L. Stimson Center - a security-policy thinktank in Washington DC - was that US officials lacked contacts inside the super-secret Soviet bioweapons network. "The biological non-proliferation programme literally had to be started from scratch," she says. As a result, more than half of the staff at Obolensk and Vector melted away during the 1990s to where, no one knows for sure.

Obolensk and Vector were two research powerhouses in a network of facilities spread throughout the Soviet Union, known collectively as 'Biopreparat' (see map, above). This network weaponized diseases such as plague, anthrax, tularaemia, brucellosis and smallpox, behind the façade of a state-run pharmaceutical enterprise. Scientists at Obolensk and Vector even genetically engineered bacteria to resist antibiotics. In addition to the staff's expertise, the centres have containment labs for working on dangerous pathogens - the provision of which is currently a limiting factor in US plans to ramp up biodefence research.

With Russia now suffering epidemics of diseases such as tuberculosis and AIDS, it stands to benefit from projects that would redirect the expertise at Obolensk and Vector to these problems. "Russia is a time bomb right now," says Ann Harrington, who studies options for reducing the threat of bioweapons at the National Defense University in Washington DC. "It has an enormous need for facilities that can support public health, and that can monitor and identify disease."

In her former job as acting director of the 


\section{Blazing the trail}

Jens Kuhn describes himself as a "microbe nerd". Having a particular fascination with the Ebola virus and related killers - known as haemorrhagic viruses - this young German virologist was delighted to become the first Western scientist to work at the bench in the heart of the former Soviet bioweapons establishment.

Kuhn's "good fortune", as he puts it, began in autumn 2000 when he found himself chatting with an official from the Pentagon at the inauguration in Stockholm of Sweden's first level-4 containment facility for handling dangerous pathogens. In his short career, Kuhn had already worked in South Africa, South Korea and at the US Army Medical Research Institute of Infectious Diseases in Fort Detrick, Maryland, where he had spent a year, until April 1999, preparing a master's thesis on the development of Ebola vaccines.

Kuhn had also started to survey the open literature on Ebola, and had contacted researchers at Vector, the State Research Center of Virology and Biotechnology near Novosibirsk in Siberia, who had begun publishing, in Russian, in 1992. He was surprised to get a swift answer from this formerly secretive bioweapons lab.

"They were just as keen for acknowledgement of their work as any other scientists," says Kuhn.

The contact spawned the idea of a visit to Vector, "which seemed impossible at the time", he says.

\section{Lucky break}

But thanks to his meeting with the Pentagon official, that mission suddenly became possible. The official recognized that Kuhn - young, intelligent, idealistic yet experienced - was exactly the sort of person to serve as a test case for a new Pentagon-sponsored programme, administered by the International Science and Technology Center (ISTC) in Moscow, to send young scientists to work for extended periods in former Soviet bioweapons labs, to help support the labs' conversion to peaceful projects.

Within nine months of that chance meeting, Kuhn was at Vector as a temporary employee of the Science Applications International Corporation, a contractor for the US Department of Defense. Vector's buildings and equipment were ramshackle, Kuhn says, but his welcome from the lab's rank and file was warm. "The scientists supported me in what I wanted to do, and also invited me to all their parties and celebrations," he says. "They treated me like a colleague although I was only a student."

But Vector's leaders seemed more suspicious. Kuhn spent his first five weeks in Siberia locked out of the lab, continuing a debate about which research project he should undertake, and overcoming numerous bureaucratic obstacles. $\mathrm{He}$ had medical checks with 12 doctors, including a psychiatrist who spent three hours determining if he was mentally stable. He had to study for, and pass, a biosafety exam in Russian. "I don't suspect it to be delaying tactics but we'll only

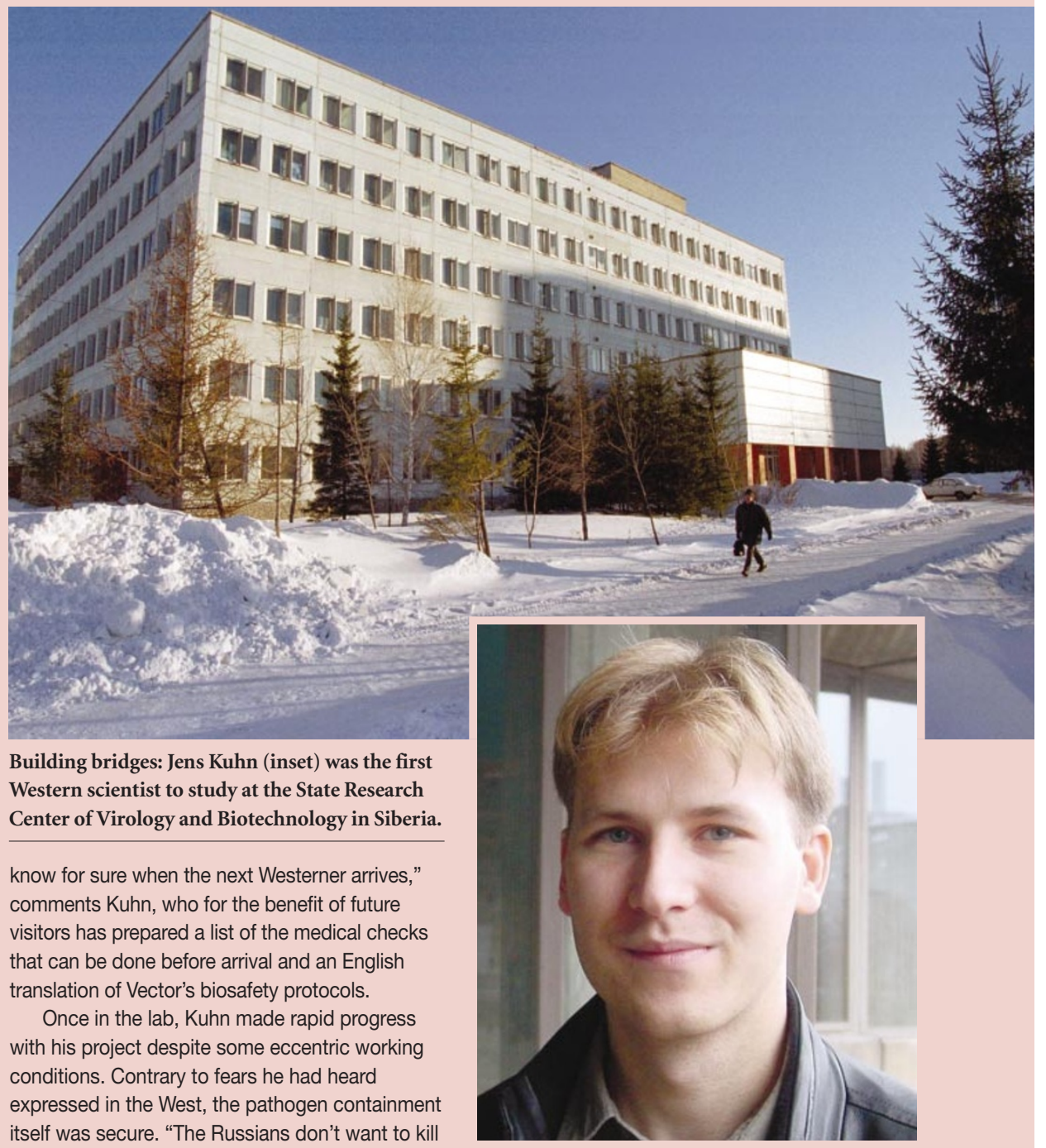
themselves any more than Western scientists," Kuhn says. Any safety problems arose from smaller economies, such as the absence of a red light in the darkroom, which meant stumbling blindly while holding biological samples, electrophoresis equipment that threatened electric shocks to the unwary, and the failure to repair uneven stairs. "I dropped one of my immunoassays the first time I went downstairs to read my samples," says Kuhn.

\section{Screen star}

Thanks to Kuhn's reports back to the ISTC, conditions improved over time. More rubber gloves and pipette tips were shipped to Vector, for instance, after Kuhn found his Russian colleagues removing his discarded supplies from the bin.

Over the course of some four months, Kuhn studied the Crimean-Congo haemorrhagic fever virus, which causes hundreds of infections each year in central Asia. He screened some 1,500 samples taken from patients, autopsies and ticks, the carriers of the disease, which had been collected from all over the former Soviet Union, and characterized seven distinct viral strains.

"The project was not 'fancy'," says Kuhn, "but was absolutely essential for understanding the epidemiology of strains, which is necessary for developing vaccines and diagnostic kits."

Kuhn, who is now looking for a postdoctoral position, believes that other virologists have much to gain from following his lead. Despite a tendency towards descriptive research, with numerous parameters but few solid conclusions, Kuhn is convinced that Vector's scientists have what it takes to compete internationally. "All they need is the right equipment," he says.

"My time at Vector was well-spent," says Kuhn, "both in terms of life experience and in terms of science." Indeed, he hopes to make a more extended visit in future, should the ISTCadministered programme provide further funds. "It's not only my passion for the haemorrhagic bugs they have there," Kuhn explains. "I also like the idea of helping to make this world a little bit safer by moving ahead the transformation of Vector to a civilian centre."

Alison Abbott 


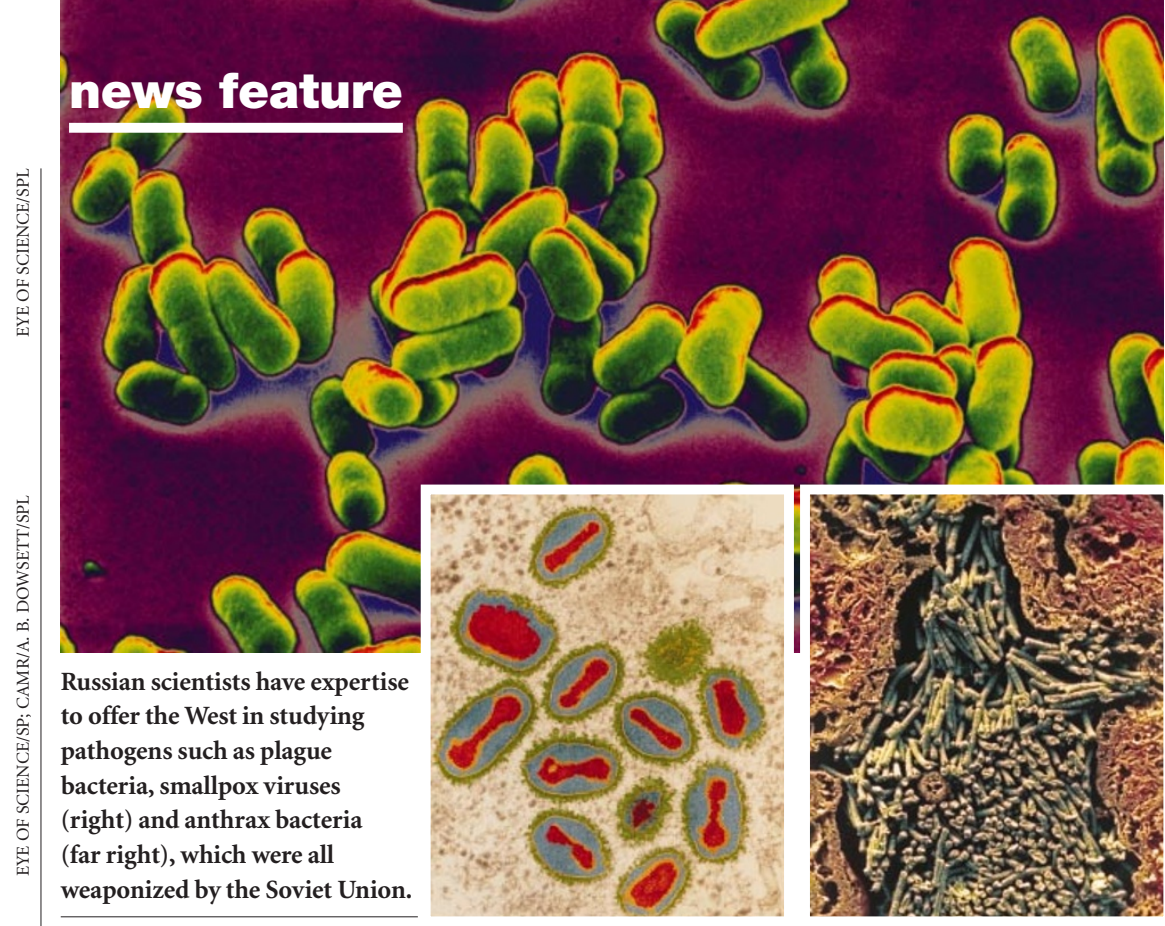

US state department's Office of Proliferation Threat Reduction, Harrington helped to set up the programme that took Morton and her colleagues to Obolensk. The modus operandi of this scheme, funded by the US Department of Defense and administered by the US National Academies, is to build partnerships between Western academics and the former Soviet bioweapons establishment. A sister programme, run by the International Science and Technology Center (ISTC), a non-proliferation organization in Moscow funded in most part by the European Union, Japan and the United States, aims to pay for more extended visits by foreign scientists to former Soviet bioweapons labs (see 'Blazing the trail', previous page).

\section{Take your partners}

Under the National Academies scheme, researchers are paid to travel to Obolensk or Vector for up to two weeks in search of partnerships. If they find a Russian to work with, they draw up a proposal, which is reviewed by the US academies' National Research Council, and can win up to $\$ 10,000$. The idea is that participants will then apply for further grants from the Pentagon, the ISTC or other non-proliferation bodies.

Researchers selected for the first round of visits went to Russia in autumn 2001. "I had this idea that I could essentially extend my lab and also switch to interesting organisms that I wouldn't be able to study in the United States," says Konstantin Severinov, a microbiologist of Russian extraction who now works at Rutgers University in New Jersey.

But so far, little progress has been made towards realizing the programme's potential. At a National Academies meeting in Washington DC last December, Severinov and Gregory Ebel, an immunologist with the New York State Department of Health in Slingerlands, expressed their frustration.
Severinov, who studies viruses called phages that infect bacteria, said that his research at Obolensk has slowed to a crawl, and Ebel explained that both US and Russian customs officials were blocking transport of even the most simple equipment.

The problems have several causes, but many stem from the secretive culture of Biopreparat. For decades, the network's scientists were cut off from the outside world, other Russian researchers and even each other. Unsurprisingly, they are not familiar with the grant writing, publication and peer review that underpins mainstream science.

At higher levels, trust continues to be an issue. Many senior managers at Obolensk and Vector are veterans from the Soviet era and have a deep mistrust of the United States. They have almost absolute authority over their labs - determining what can flow to the West, and having an obligation to the Russian state to protect classified research. "Scientists may be convicted for giving state secrets to foreigners," says Ken Alibek, who served as deputy director of Biopreparat for five years before defecting to the United States in 1992.

As a result of these attitudes, some US politicians complain that the Russian labs are simply trying to take cash handouts without opening themselves up to proper scrutiny. "We must ensure that the investment can be directly traced to an actual tangible reduction in military threats," the chair of the House of Representatives Armed Services Committee, Duncan Hunter (Republican, California), said at a hearing in January. Suspicions about the new schemes are heightened by the experience of earlier non-proliferation programmes established in the former Soviet Union, which have been plagued by corruption: lab administrators have been known to take a cut from each research grant at their facility.

Today, financial checks are in place to prevent such abuses, but these also slow research.
Following a congressional crackdown, for instance, there are now strict limits on how much of the funding can be spent by US researchers on projects in Russia. "We have some money for travel," says Bruce Scharf, a veterinary scientist at the State University of New York's Downstate Medical Center in Brooklyn, who is setting up a project to study rabies at Vector under the National Academies programme. "But I'm not paid a cent."

\section{Closed borders}

Perhaps the most serious problems are those caused by customs and immigration restrictions. Especially since the terrorist outrages of 11 September 2001, and the anthrax attacks that followed, the US customs service has enforced strict controls on the import of biological material. As a result, Scharf has been unable to get the rabies samples he is studying at Vector into the United States. Similarly tough regulations on both the US and Russian sides are preventing Sergey Morzunov, a Russian-born microbiologist at the University of Nevada at Reno, from sending even basic materials, such as reagents for a DNA sequencing kit, to Vector. "The expiry date for my sequencing kit is May 2003, but it is still sitting on a shelf in the warehouse," Morzunov complains.

New immigration regulations have also stopped Russian partners in the programme from visiting the United States to build links with their new Western colleagues, adds Vladimir Volkov, deputy director of the Obolensk facility. "Getting a visa for a business trip to the States may now take over three months," he says.

Given the litany of problems, Alibek doubts whether the programmes will do much to further the cause of non-proliferation - especially as so many Obolensk and Vector staff drifted away in the 1990s. But other experts point to the vast expertise on biological warfare still present at the centres, and argue that it must be worth harnessing this knowledge. "I think the programme is still very much in its infancy," says Glenn Schweitzer, its coordinator at the US National Academies.

Despite the difficulties he has experienced, Severinov remains committed to the goal of drawing the former outcasts of Biopreparat into the international scientific community. He and his collaborators have nearly finished two papers, the first of which he hopes will be published later this summer. And Severinov is now applying for a larger grant that would permit him to extend his collaboration at Obolensk for three more years. "These people must have joined those institutes because they like science," he says. "I think they just have to be put into the mainstream."

Geoff Brumfiel is Nature's Washington physicalsciences correspondent.

www7.nationalacademies.org/dsc/

biomedical_exchange_program.html 